\title{
In-vitro and in-vivo responsiveness of the corpus luteum of the mare to gonadotrophin stimulation
}

\author{
C. M. Kelly, P. B. Hoyer and M. E. Wise \\ Departments of Animal Sciences and Physiology, University of Arizona, Tucson, AZ 85721, U.S.A.
}

\begin{abstract}
Summary. Dispersed horse luteal cells were used to evaluate the ability of horse LH, hCG and PMSG to stimulate progesterone secretion in vitro. Morphological characterization of these cells before gonadotrophin stimulation indicated the presence of two populations of cells based on cell diameters. In luteal cells incubated as suspended cells, horse LH and hCG stimulated $(P \leqslant 0.05)$ progesterone production at all levels of treatment. Stimulation of progesterone secretion by hCG was greater $(P \leqslant 0.05)$ than by horse $\mathrm{LH}$ over the range of concentrations utilized.

When mares $(\mathrm{N}=7)$ received an intramuscular injection of 1000 i.u. hCG on Days 3,4 and 5 after the end of oestrus, there was an increase $(P \leqslant 0.05)$, in peripheral progesterone concentrations beginning on Day 7 and continuing until Day 14 compared with controls $(\mathrm{N}=7)$. Peripheral progesterone concentrations continued to be elevated in hCG-treated mares for Days 15-30 after oestrus in those mares that conceived. Although treatment with hCG increased progesterone concentrations, it had no influence on anterior pituitary release of LH as measured by frequency and amplitude of $\mathrm{LH}$ discharge.

We conclude that the mare corpus luteum is responsive to gonadotrophins in vitro and that exogenous hCG can enhance serum progesterone concentrations throughout the oestrous cycle and early pregnancy.
\end{abstract}

Keywords: progesterone; mare; LH; corpus luteum

\section{Introduction}

Stimulation of progesterone production by luteal cells in vitro with luteinizing hormone (LH) has been demonstrated for several species (Lemon \& Mauleon, 1982; Fitz et al., 1982; Milvae et al., 1983; Carnegie \& Tsang, 1984; Eyster \& Stouffer, 1985). Human chorionic gonadotrophin (hCG) has also been shown to be effective in stimulating progesterone secretion by luteal cells in a number of species (Moyle, 1980; Ziecik et al., 1980; Bourdage et al., 1984; Ottobre et al., 1984). While pregnant mare serum gonadotrophin (PMSG) binds to rat, cow and pig luteal gonadotrophin receptors with approximately the same efficiency on a molar basis as hCG and LH, PMSG binds to LH receptors of mares with about one-tenth the affinity of receptors in other species (Stewart \& Allen, 1979). The ability of these gonadotrophins to stimulate progesterone secretion from mare luteal cells in vitro has not been characterized.

In the mare, as in other species, gonadotrophins are the putative regulators of progesterone secretion. Regulation of progesterone secretion by gonadotrophins appears to entail direct as well as indirect actions. Within the corpus luteum of several species there are two distinct steroidogenic cell types commonly referred to as small and large luteal cells (Ursely \& Leymari, 1979; Fitz et al., 1982; Hoyer et al., 1984, 1986). Since these cell types have different steroidogenic capacities (Fitz et al., 1982) changes in their relative abundance could dramatically influence progesterone output by the corpus luteum. Administration of hCG during various stages of the oestrous cycle in sheep 
(Gamboni et al., 1984; Farin et al., 1988) has been shown to elevate serum progesterone concentrations over prolonged periods of time. One putative action of hCG in elevating progesterone concentration is by altering the cellular composition of the corpus luteum. In cyclic ewes, several studies (O'Shea et al., 1986; Farin et al., 1986) have been unable to measure increases in numbers of large steroidogenic luteal cells as the oestrous cycle progressed. However, an increased proportion of large relative to small cells was demonstrated in corpora lutea recovered from cyclic (Farin $e t$ al., 1988) or superovulated (Gamboni et al., 1984) ewes injected with hCG during the luteal phase of the oestrous cycle. This suggests a role for hCG $(\mathrm{LH})$ in promoting the conversion of small to large cells. The presence of more than one steroidogenic cell type within the corpus luteum of the mare has not been confirmed and little information is available with regard to gonadotrophin regulation of progesterone secretion in this tissue.

The objectives of the present study were: (1) to examine the possibility that more than one steroidogenic cell type exists in the corpus luteum of the mare, (2) to examine the effectiveness of LH, hCG and PMSG in stimulating progesterone secretion in vitro, and (3) to determine whether hCG treatment during the early luteal phase of the mare would stimulate progesterone secretion throughout the oestrous cycle and early pregnancy.

\section{Materials and Methods}

Experiment 1. Mares were teased daily beginning in February and oestrous cycles followed to ensure that all mares were cycling normally before collection of corpora lutea. Corpora lutea were collected from 7 mares during the mid-luteal phase of the oestrous cycle (Day 8-10; last day of oestrus = Day 0) during the months of May and June. Mares were anaesthetized with a combination of xylazine, butophanol tartrate and acepromazine. Lidocaine was administered into the upper lumbar region of the flank on the side that ovulation had occurred. Excised ovaries were immediately placed in sterile Medium 199 (Gibco Laboratories, Grand Island, NY), pH 7.5, and transported to the laboratory. The corpora lutea were dissected free from the ovary, sliced and dissociated in medium which consisted of complete Hank's medium containing $0.4 \%$ collagenase, $0.005 \%$ deoxyribonuclease and $1 \%$ bovine serum albumin. Dissociation of cells was performed with gentle shaking. Some corpora lutea appeared to be more resistant to the mild conditions of dissociation; therefore, the tissue was incubated at $37^{\circ} \mathrm{C}$ in an atmosphere of $95 \% \mathrm{O}_{2}-5 \% \mathrm{CO}_{2}$ for $2-10 \mathrm{~h}$ with frequent agitation by aspiration to disperse cells. No differences in cell viability of relative proportions of large to small cells were obvious over the various dissociation times.

Cell viability was determined by trypan blue exclusion and varied from 70 to $99 \%$. This value was used to determine the number of viable cells for incubation.

Cells were stained for $3 \beta$-hydroxy- $\Delta^{5}$-steroid dehydrogenase- $\Delta^{5}, \Delta^{4}$-isomerase $(3 \beta$-HSD) activity to determine steroidogenic capacity according to the procedure of Payne et al. (1980). Diameters of $3 \beta$-HSD-positive cells were measured with an inverted microscope equipped with a calibrated ocular micrometer $(1.7 \mu \mathrm{m}$ per unit; $\times 300 ; 300$ cells per observation).

Suspended cells $(25000 \mathrm{cells} / \mathrm{ml})$ were incubated, at $37^{\circ} \mathrm{C}$ in $12 \times 75 \mathrm{~mm}$ glass tubes containing $2 \mathrm{ml} \mathrm{Medium} 199$, for $2 \mathrm{~h}$ in an atmosphere of air with gentle shaking. The incubation tubes were sealed to prevent evaporation. The medium contained horse LH (HP-E98A: $3.0 \times 10^{-6}$ to $3.0 \times 10^{-10} \mathrm{mmol} / \mathrm{tube}$ : Licht et al., 1979); hCG (Sigma Chemicals, St Louis, MO: $9.0 \times 10^{-7}$ to $9.0 \times 10^{-11} \mathrm{mmol} /$ tube); PMSG (PM82B1: $4.0 \times 10^{-6}$ to $4.0 \times 10^{-10} \mathrm{mmol} / \mathrm{tube}, 4000 \mathrm{i} . \mathrm{u} . / \mathrm{mg}$ ); or no hormone. PMSG was purified as previously described (Matteri et al., 1986). At the end of incubation, cells were pelleted by centrifugation $(900 \mathrm{~g})$ and medium was collected and stored $\left(-20^{\circ} \mathrm{C}\right)$ for subsequent radioimmunoassay for content of progesterone.

Experiment 2 . Sexually mature, normally cycling mares were randomly assigned to a control group $(\mathrm{N}=7)$ or were treated with hCG $(\mathrm{N}=7)$ in the months of May and June. Mares were balanced across treatments by their reproductive status (post partum or barren). Control mares received no injection and the treatment mares received an intramuscular injection of $1000 \mathrm{i} . \mathrm{u}$. hCG on Days 3,4 and 5 after the end of oestrus (last day of oestrus = Day 0 ). Mares were checked for oestrus once daily by teasing with a stallion and when found to be in oestrus were artificially inseminated every other day until the cessation of oestrus.

Daily blood samples for progesterone analysis were taken via jugular venepuncture. Serial blood samples for $\mathrm{LH}$ analysis were collected at 12-min intervals for an 8-h period using an indwelling jugular catheter on Days 4 or 5 and Days 12 or 13 after oestrus.

Assays. Progesterone concentrations were measured in reconstituted petroleum ether extracts of duplicate samples of serum or incubation medium by a radioimmunoassay previously described (Niswender, 1973), using antiserum raised in rabbits against progesterone-11-hemisuccinate-BSA. Cross-reactivity of the antibody was $1 \%$ for oestradiol-

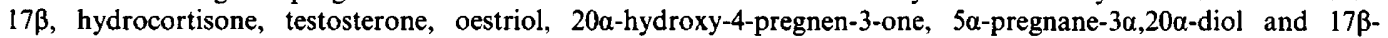


hydroxyprogesterone. Intra- and inter-assay coefficients of variation were $7.5 \%$ and $14.6 \%$ respectively. Sensitivity, as determined by $90 \%$ inhibition of binding, was $25 \mathrm{pg} /$ tube.

Plasma LH was analysed by a modification of the method described by Niswender et al. (1969), using ${ }^{125}$ I-labelled sheep LH (LER-1056-62), anti-ovine LH antibody (GDN-15) and a highly purified preparation of horse LH (HPE98A) as standards. Cross-reactivity of the LH antibody with hCG was $<1 \%$. The sensitivity of the assay was $0.8 \mathrm{ng} / 200 \mu \mathrm{l}$ serum. Intra- and inter-assay coefficients of variation were 6.0 and $13.3 \%$, respectively.

Differences in concentrations of progesterone or characteristics of $\mathrm{LH}$ release were evaluated by multivariant analysis of variance for repeated measures. Progesterone data were divided into two segments for analysis, the phases of increasing (Days 1-6) and decreasing (Days 7-14 of the cycle or Days 7-30 of gestation) progesterone concentrations. Characteristics of LH release were determined using a computerized algorithm (Veldhuis \& Johnson, 1986).

\section{Results}

\section{Experiment 1}

Morphological analysis of steroidogenic luteal cells revealed two distinct subpopulations of cells, based on cell size (Fig. 1). Most of the cells were 7 to $18 \mu \mathrm{m}$ in diameter. The second distinct subpopulation of cells had a diameter of $18-25 \mu \mathrm{m}$ and appeared to be less abundant than the smaller cell type.

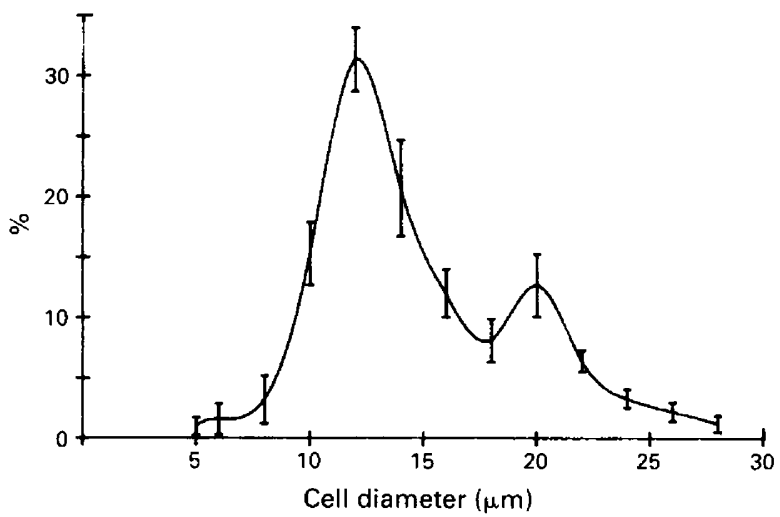

Fig. 1. Size distribution of $3 \beta$-HSD-positively stained cells (mean \pm s.e.m.) as a percentage of total steroidogenic cells $(\mathrm{N}=7)$.

In suspended cell incubations, horse $\mathrm{LH}$ and hCG stimulated secretion of progesterone $(P<0.01)$ above controls at all doses tested (Fig. 2). There was a linear increase in secretion of progesterone with increasing concentrations of horse LH and hCG (Fig. 2). Differences in slopes of the dose-responses $(P<0 \cdot 10)$ indicated that responsiveness to hCG was greater than for horse LH. At all doses, hCG was more effective on a millimolar basis in stimulating progesterone release (Fig. 2). There were no concentrations of PMSG which stimulated a significant increase in progesterone production (data not shown).

\section{Experiment 2}

Through Day 7, circulating progesterone concentrations were similar in each treatment group (Figs 3 \& 4). Analysis of progesterone data showed no differences due to pregnancy status through Day 14, and so the data were pooled into hCG-treated and untreated groups. Treatment with hCG in vivo resulted in an overall increase $(P<0.05)$ in progesterone secretion in all treated mares until Day 14. Daily progesterone concentrations were higher $(P<0.05)$ in hCG-treated mares on Days 


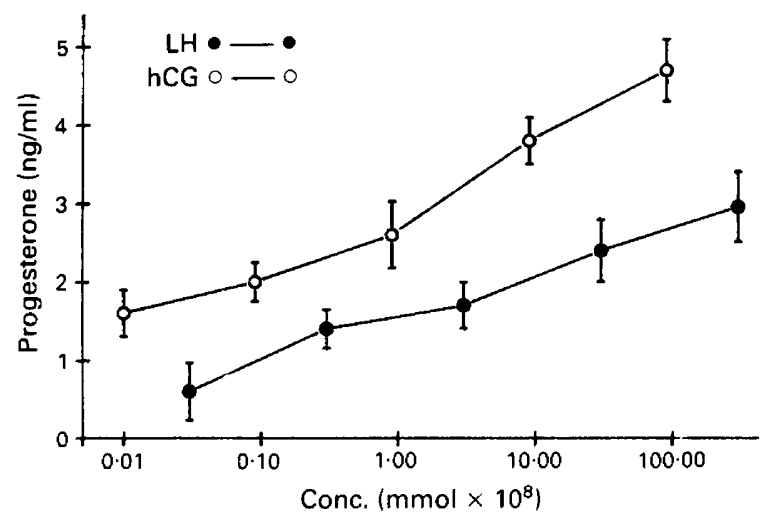

Fig. 2. Stimulation of progesterone secretion in horse luteal cells by horse LH and hCG. Values depicted (mean \pm s.e.m.; $N=7$ ) are ng progesterone $/ 25000$ cells. Basal secretion of progesterone in control cells averaged $0 \cdot 2 \mathrm{ng} / 25000$ cells.

7-14 compared to controls (Fig. 3). Progesterone concentrations remained elevated above those of controls over Days 17-30 in those mares treated with hCG that conceived (Fig. 4). Characteristics of LH release examined (overall mean, number of pulses, pulse amplitude; Table 1) were not different in control and hCG-treated mares. Although hCG treatment raised peripheral progesterone concentrations, there was no difference in pregnancy rate. In the hCG-treated group, 3 of 7 mares became pregnant compared with 4 of 7 in the control group. There were no statistical interactions detected between treatment and previous reproductive status (post partum or previously barren) for progesterone concentrations or LH parameters.

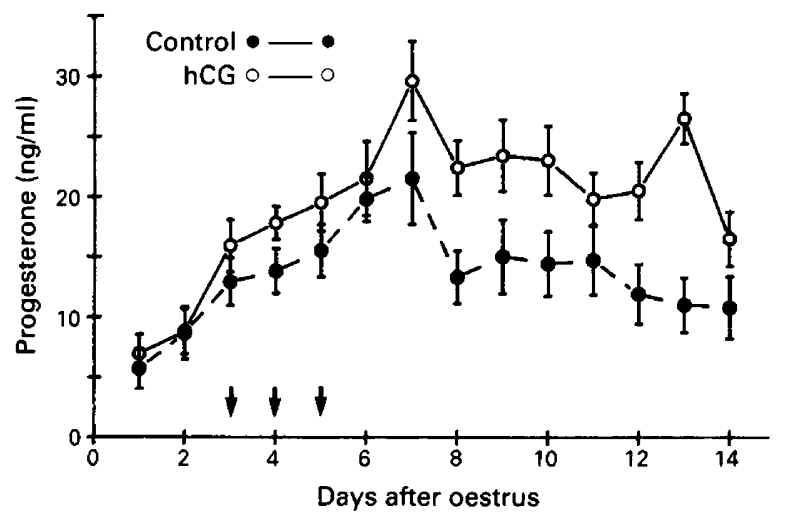

Fig. 3. Concentrations of progesterone (mean \pm s.e.m.) in control $(\mathrm{N}=7)$ and hCG-treated $(\mathrm{N}=7)$ mares from Day 1 to Day 14 of the oestrous cycle. Arrows indicate days when hCG (1000i.u.) was administered. Progesterone concentrations were higher $(P<0.05)$ in hCG-treated mares than in controls from Day 7 to 14.

\section{Discussion}

On the basis of cell diameter, there appear to be two distinct luteal cell subpopulations in the mare (Fig. 1). This is consistent with reports for other animals such as ewes (O'Shea et al., 1979), sows 


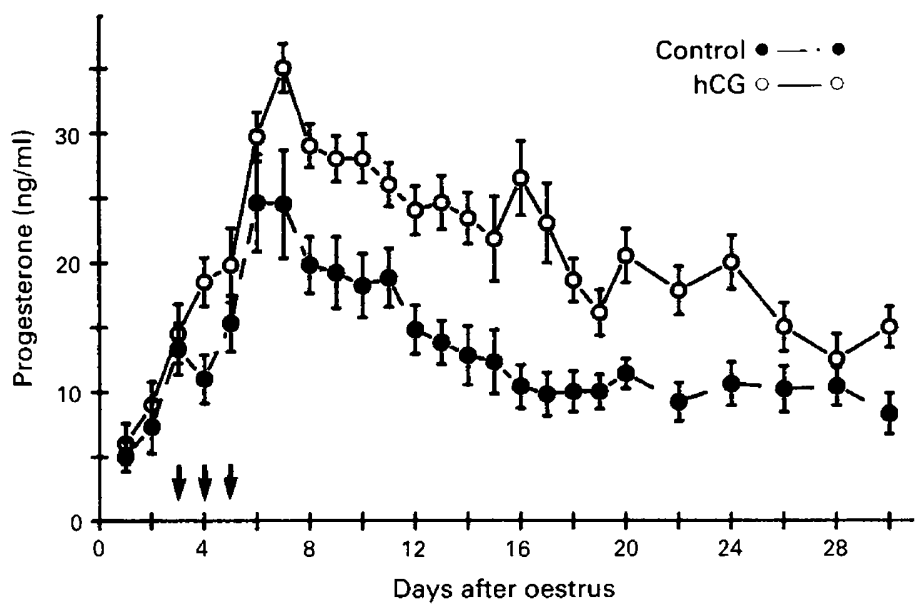

Fig. 4. Concentrations of progesterone (mean \pm s.e.m.) in pregnant control $(\mathrm{N}=4)$ and hCGtreated mares $(\mathrm{N}=3)$. Arrows indicate days when hCG $(1000$ i.u.) was administered to mares treated with hCG. Progesterone concentrations were higher $(P<0 \cdot 05)$ in hCG-treated mares than in controls from Day 7 to 30 .

Table 1. Mean plasma LH concentrations ( \pm s.e.m.), number of $\mathrm{LH}$ pulses $/ 8 \mathrm{~h}$ and $\mathrm{LH}$ pulse amplitude of hCG-treated (1000 i.u. on Days 3,4 and 5) and control mares on Days 4-5 and 12-13 of the oestrous cycle

\begin{tabular}{lrrrrr}
\hline & \multicolumn{2}{c}{ hCG } & & \multicolumn{2}{c}{ Control } \\
\cline { 2 - 3 } \cline { 5 - 6 } & \multicolumn{1}{c}{ Days 4-5 } & Days 12-13 & & Days 4-5 & \multicolumn{1}{c}{ Days 12-13 } \\
\hline Mean LH (ng/ml) & $25 \cdot 6 \pm 6 \cdot 2$ & $19 \cdot 5 \pm 4 \cdot 1$ & & $29 \cdot 7 \pm 7 \cdot 0$ & $20 \cdot 8 \pm 1 \cdot 7$ \\
Pulses/8 h & $1 \cdot 3 \pm 0 \cdot 5$ & $2 \cdot 0 \pm 0.5$ & & $0 \cdot 8 \pm 0 \cdot 4$ & $1 \cdot 3 \pm 0 \cdot 5$ \\
Pulse amplitude (ng/ml) & $44 \cdot 2 \pm 11 \cdot 9$ & $41 \cdot 5 \pm 6 \cdot 4$ & & $33 \cdot 5 \pm 4 \cdot 9$ & $35 \cdot 2 \pm 14 \cdot 3$ \\
\hline
\end{tabular}

(Lemon \& Loir, 1977), rabbits (Hoyer et al., 1986) and cows (Ursely \& Leymarie et al., 1979). Whether the responsiveness of these cell types to LH is different, as it is in other species (Lemon \& Loir, 1977; Ursely \& Leymarie, 1979; Fitz et al., 1982; Rodgers et al., 1983; Hoyer et al., 1984, 1986), is unknown since mixed cell populations were utilized in this study. However, the ability of hCG to augment progesterone concentrations in vivo from Days 7 to 14 (Fig. 3) indicates that responsiveness of the mare in vivo to hCG is similar to that observed in the ewe (Gamboni et al., 1984; Farin et al., 1988). If these changes in progesterone secretion after hCG administration are due to changes in the cellular composition of the corpus luteum as proposed for the ewe (Gamboni et al., 1984; Farin et al., 1988), then it would seem reasonable that the cell types in the mare are functionally similar to the distinct steroidogenic luteal cell types described for other species. Alternatively, an increase in progesterone concentrations might be due to increases in numbers of steroidogenic cells or amount of luteal tissue.

In the present study hCG effectively stimulated secretion of progesterone by the mare corpus luteum in vitro and in vivo. This may be due to the ability of the hCG molecule to bind to the LH receptor on the corpus luteum, as has been demonstrated for the rat (Moyle, 1980), ewe (Mock \& 
Niswender, 1983), pig (Ziecik et al., 1980), monkey (Eyster \& Stouffer, 1985) and mare (Roser et al., 1982). In vitro, hCG appears to be much more effective than horse LH in stimulating progesterone secretion based on the hormone preparations used. In cultured rat Leydig cells, Segaloff et al. (1981) also found that hCG was more effective in stimulating progesterone secretion than was LH. This difference in effectiveness may be related to the rate of internalization of the two proteins. The results of Mock \& Niswender (1983) demonstrated that hCG bound to the LH receptor of sheep luteal cells is internalized 50 times slower than is LH bound to the same receptor. Presumably, the reduced rate of internalization of the LH receptor in the luteal cell membrane when bound to hCG is responsible for the prolonged ability of hCG to stimulate progesterone secretion (Bourdage et al., 1984). It has been shown that persistent occupancy of the LH receptor by hCG is required for continued activation of the adenylate cyclase system (Abramowitz \& Birnbaumer, 1982 ) and that removal of the hormone from the receptor results in a decrease in adenylate cyclase activity.

The inability of PMSG to stimulate progesterone production at any level of treatment is not surprising since horse luteal LH receptors apparently do not avidly bind PMSG (Roser et al., 1982; Stewart \& Allen, 1979) and horse luteal tissue does not have specific receptors for PMSG (Stewart \& Allen, 1979). The inability of PMSG to stimulate progesterone in the present study also suggests that this hormone does not act to stimulate secretion of progesterone through a receptor system other than that for $\mathrm{LH}$ in the corpus luteum formed during the oestrous cycle of the mare. Regulation of the secretion of progesterone in the corpus luteum of the oestrous cycle, however, may be different from that of secondary corpora lutea formed during pregnancy.

The ability of hCG to enhance progesterone secretion in vitro was also demonstrated in vivo. The effects of hCG administration in vivo on progesterone concentrations, however, were not observed on the days of administration (Fig. 3). The latency of the progesterone response to hCG suggests that functional changes may have occurred in the corpus luteum after hCG treatment. The nature of these changes may reflect an alteration in steroidogenic cell types within the corpus luteum. In the ewe, the small luteal cell type contains the majority of LH receptors and is responsive to LH stimulation (Fitz et al., 1982). The small cell stimulated by LH may represent the principal source of luteal progesterone (Rodgers et al., 1983). The large cell is not responsive to LH, its basal secretion of progesterone is 10 times that of the small cell and may significantly contribute to the amount of progesterone secreted by the corpus luteum (Fitz et al., 1982). If hCG, when given to mares on Days 3-5, enhanced a transformation of small to large cells, then progesterone concentration should remain elevated until regression of the corpus luteum. This was the case in the present study in all cyclic mares until Day 14 (Fig. 3) and in pregnant mares until Day 30 (Fig. 4). The differences in progesterone concentrations throughout the oestrous cycle and to Day 30 in pregnant mares (Fig. 4) were apparently due to hCG treatment and not to changes in endogenous LH secretion.

An alternative explanation for the prolonged elevation of progesterone concentrations in hCGtreated mares is that additional luteal tissue was formed after administration of hCG. Although mares were palpated after injection of hCG and no additional corpora lutea were found, luteinized follicles may not have been detected. If the dose of hCG used in the present study (3-5 times below that normally used to induce ovulation) did luteinize follicles, a rapid increase in serum progesterone concentrations would be anticipated. Increases in serum progesterone after induction of ovulation normally occur within $24-48 \mathrm{~h}$ (Michel et al., 1986). This was not the case in the present study as an increase in serum progesterone concentrations above controls was not found until 4 days after the first injection of hCG (Fig. 3).

Despite elevated progesterone concentrations in hCG-treated mares, release of LH in these mares was not different from that in controls (Table 1). These results suggest that $\mathrm{LH}$ release in the mare is not subject to extremely sensitive feedback regulation by progesterone. Progesterone does inhibit LH secretion in ovariectomized mares (Garcia \& Ginther, 1978) but these effects are much less pronounced compared to the negative feedback effect of oestradiol and progesterone in 
combination. Alternatively, if progesterone feedback inhibition of LH release was maximal in control mares, further suppression of LH release by progesterone in hCG-treated mares would not be expected to occur.

In conclusion, these results support the concept that two steroidogenic cell types are present in the corpus luteum of the mare during dioestrus. These cells are responsive to gonadotrophin stimulation both in vitro and in vivo. Additional gonadotrophin stimulation in vivo results in prolonged elevation of serum progesterone secretion without influencing endogenous $\mathrm{LH}$ secretion.

This paper is journal publication no. 4490 of the Arizona Agriculture Experiment Station. We thank Dr G. D. Niswender for antiovine LH antiserum; Dr L. E. Reichert, Jr for purified ovine LH; Dr H. Papkoff for purified horse LH and PMSG; and Bill Schurg, Tom Toneff, Dianna Amado and Ann Petrasek for technical assistance.

\section{References}

Abramowitz, J. \& Birnbaumer, L. (1982) Temporal characteristics of gonadotropin interaction with rabbit luteal receptors and activation of adenylyl cyclase: comparison to the mode of action of catecholamine receptors. Endocrinology 111, 970-975.

Bourdage, R.J., Fitz, T.A. \& Niswender, G.D. (1984) Differential steroidogenic responses of ovine luteal cells to ovine luteinizing hormone and human chorionic gonadotropin. Proc. Soc. exp. Biol. Med. 175, 483-486.

Carnegie, J.A. \& Tsang, B.K. (1984) The calciumcalmodulin system; participation in the regulation of steroidogenesis at different stages of granulosa cell differentiation. Biol. Reprod. 30, 515-520.

Eyster, K.M. \& Stouffer, R.L. (1985) Adenylate cyclase in the corpus luteum of the rhesus monkey. II. Sensitivity to nucleotides, gonadotropins, catecholamines and nonhormonal activators. Endocrinology 116, 1552-1558.

Farin, C.E., Moeller, C.L., Sawyer, H.R., Gamboni, F. \& Niswender, G.D. (1986) Morphometric analysis of cell types in the ovine corpus luteum throughout the estrous cycle. Biol. Reprod. 35, 1299-1308.

Farin, C.E., Moeller, C.L., Mayan, M.H., Gamboni, F., Sawyer, H.R. \& Niswender, G.D. (1988) Effect of luteinizing hormone and human chorionic gonadotropin on cell populations in the ovine corpus luteum. Biol. Reprod. 38, 413-421.

Fitz, T.A., Mayan, M.H., Sawyer, H.R. \& Niswender, G.D. (1982) Characterization of two steroidogenic cell types in the ovine corpus luteum. Biol. Reprod. 27, 703-711.

Gamboni, F., Fitz, T.A., Hoyer, P.B., Wise, M.E., Mayan, M.H. \& Niswender, G.D. (1984) Effect of human chorionic gonadotropin on induced ovine corpora lutea during the anestrous season. Dom. Anim. Endocrinol. 1, 79-88.

Garcia, M.C. \& Ginther, O.J. (1978) Regulation of plasma LH and FSH by estradiol and progesterone in ovariectomized mares. Biol. Reprod. 19, 447-453.

Hoyer, P.B., Fitz, T.A. \& Niswender, G.D. (1984) Hormone-independent activation of adenylate cyclase in large steroidogenic ovine luteal cells does not result in increased progesterone secretion. Endocrinology 114, 604-608.
Hoyer, P.B., Keyes, P.L. \& Niswender, G.D. (1986) Size distribution and hormonal responsiveness of dispersed rabbit luteal cells during pseudopregnancy. Biol. Reprod. 34, 905-910.

Lemon, M. \& Loir M. (1977) Steroid release in vitro by two luteal cell types in the corpus luteum of the pregnant sow. J. Endocr. 72, 351-359.

Lemon, M. \& Mauleon, P. (1982) Interaction between two luteal cell types from the corpus luteum of the sow in progesterone synthesis in vitro. J. Reprod. Fert. 64, 315-323.

Licht, P., Gallo, A.B., Aggarwal, B.B., Farmer, S.W., Castelino, J.B. \& Papkoff, H. (1979) Biological and binding activities of equine pituitary gonadotrophin and pregnant mare serum gonadotrophin and pregnant mare serum gonadotrophin. J. Endocr. 83, 311-322.

Matteri, R.L., Papkoff, H., Murphy, H.M.S., Roser, J.F. \& Chang, Y.S. (1986) Comparison of the properties of highly purified equine chorionic gonadotropin isolated from commercial concentrates of pregnant mare serum and endometrial cups. Dom. Anim. Endocrinol. 3, 39-48.

Michel, T.H., Rossdale, P.D. \& Cash, R.S.G. (1986) Efficacy of human chorionic gonadotrophin and gonadotrophin releasing hormone for hastening ovulation in thoroughbred mares. Equine vet. J. 18, 438- 442.

Milvae, R.A., Alila, H.W. \& Hansel, W. (1983) Methylation in bovine luteal cells as a regulator of luteinizing hormone action. Biol. Reprod. 29, 849-853.

Mock, E.J. \& Niswender, G.D. (1983) Differences in the rate of internalization of human chorionic gonadotropin, luteinizing hormone and epidermal growth factor by ovine luteal cells. Endocrinology 113, 259-264.

Moyle, W.R. (1980) Biochemistry of gonadotropin receptors. In Oxford Rev. Reprod. Biol. 2, 123-204.

Niswender, G.D. (1973) Influence of the site of conjugation of the specificity of antibodies to progesterone. Steroids 22, 413-424.

Niswender, G.D., Reichert, L.E., Jr, Midgley, A.R., Jr \& Nalbandov, A.V. (1969) Radioimmunoassay of bovine and ovine luteinizing hormone. Endocrinology 84, 1166-1173. 
O'Shea, J.D., Cran, D.G. \& Hay, M.F. (1979) The small luteal cell of the sheep. J. Anat. 128, 239-251.

O'Shea, J.D., Rodgers, R.J. \& Wright, P.J. (1986) Cellular composition of the sheep corpus luteum in the mid- and late luteal phases of the oestrous cycle. $J$. Reprod. Fert. 76, 685-691.

Ottobre, J.S., Ottobre, A.C. \& Stouffer, R.L. (1984) Changes in available gonadotropin receptors in the corpus luteum in the rhesus monkey during simulated early pregnancy. Endocrinology 115, 198-204.

Payne, A.H., Downing, J.R. \& Wong, K.L. (1980) Luteinizing hormone receptors and testosterone synthesis in two distinct populations of leydig cells. Endocrinology 106, 1424-1429.

Rodgers, R.J., O'Shea, J.D. \& Findlay, J.K. (1983) Progesterone production in vitro by small and large ovine luteal cells. J. Reprod. Fert. 69, 113-124.

Roser, J.F., Evans, J.W., Mikuckis, G.M., Adams, T.E. \& Hughes, J.P. (1982) Effect of PGF-2 $\alpha$ on LH receptors in the equine corpus luteum. J. Reprod. Fert., Suppl. 32, 235-245.
Segaloff, D.L., Puett, D. \& Ascoli, M. (1981) The dynamics of the steroidogenic response of perfused leydig tumor cells to human chorionic gonadotropin, ovine luteinizing hormone, cholera toxin and adenosine $3^{\prime}, 5^{\prime}$-cyclic monophosphate. Endocrinology 108, 632-638.

Stewart, F. \& Allen, W.R. (1979) The binding of FSH, LH and PMSG to equine gonadal tissues. J. Reprod. Fert., Suppl. 27, 441-446.

Ursely, J. \& Leymarie, P. (1979) Varying response to LH of two luteal cell types isolated from bovine corpus luteum. J. Endocr. 83, 303-310.

Veldhuis, J.D. \& Johnson, M.L. (1986) Cluster analysis: a single versatile, and robust algorithm for endocrine pulse detection. Am. J. Physiol. 250, E486-E493.

Ziecik, A., Shaw, H.J. \& Flint, A.P.F. (1980) Luteal LH receptors during the oestrous cycle and early pregnancy in the pig. J. Reprod. Fert. 60, 129-137.

Received 29 March 1988 